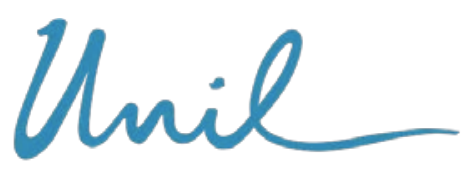

UNIL | Université de Lausanne

Unicentre

$\mathrm{CH}-1015$ Lausanne

http://serval.unil.ch

Year : 2017

\title{
Endocan concentrations in postmortem sérum, vitreous humor and urine in victims of lethal hypothermia
}

\author{
Descloux Emilienne
}

Descloux Emilienne, 2017, Endocan concentrations in postmortem sérum, vitreous humor and urine in victims of lethal hypothermia

Originally published at: Thesis, University of Lausanne

Posted at the University of Lausanne Open Archive http://serval.unil.ch

Document URN : urn:nbn:ch:serval-BIB_7745366CE3D90

\section{Droits d'auteur}

L'Université de Lausanne attire expressément l'attention des utilisateurs sur le fait que tous les documents publiés dans l'Archive SERVAL sont protégés par le droit d'auteur, conformément à la loi fédérale sur le droit d'auteur et les droits voisins (LDA). A ce titre, il est indispensable d'obtenir le consentement préalable de l'auteur et/ou de l'éditeur avant toute utilisation d'une oeuvre ou d'une partie d'une oeuvre ne relevant pas d'une utilisation à des fins personnelles au sens de la LDA (art. 19, al. 1 lettre a). A défaut, tout contrevenant s'expose aux sanctions prévues par cette loi. Nous déclinons toute responsabilité en la matière.

\section{Copyright}

The University of Lausanne expressly draws the attention of users to the fact that all documents published in the SERVAL Archive are protected by copyright in accordance with federal law on copyright and similar rights (LDA). Accordingly it is indispensable to obtain prior consent from the author and/or publisher before any use of a work or part of a work for purposes other than personal use within the meaning of LDA (art. 19, para. 1 letter a). Failure to do so will expose offenders to the sanctions laid down by this law. We accept no liability in this respect. 
UNIVERSITE DE LAUSANNE - FACULTE DE BIOLOGIE ET DE MEDECINE

Département universitaire de médecine et santé communautaires (DUMSC) Centre universitaire romand de médecine légale (CURML)

Endocan concentrations in postmortem serum, vitreous humor and urine in victims of lethal hypothermia

\section{THESE}

préparée sous la direction du Docteur Cristian PALMIERE

et présentée à la Faculté de biologie et de médecine de l'Université de Lausanne pour l'obtention du grade de

DOCTEUR EN MEDECINE

par

\section{Emilienne DESCLOUX}

Médecin diplômée de la Confédération Suisse

Originaire de Carouge (Genève)

Lausanne 


\section{UNIVERSITE DE LAUSANNE - FACULTE DE BIOLOGIE ET DE MEDECINE}

Département universitaire de médecine et santé communautaires (DUMSC)

Centre universitaire romand de médecine légale (CURML)

Endocan concentrations in postmortem serum, vitreous humor and urine in victims of lethal hypothermia

\section{THESE}

préparée sous la direction du Docteur Cristian PALMIERE

et présentée à la Faculté de biologie et de médecine de

l'Université de Lausanne pour l'obtention du grade de

DOCTEUR EN MEDECINE

par

\section{Emilienne DESCLOUX}

Médecin diplômée de la Confédération Suisse

Originaire de Carouge (Genève)

\section{Lausanne}


UNIL | Université de Lausanne

Faculté de biologie et de médecine

Ecole Doctorale Doctorat en médecine

\section{Imprimatur}

Vu le rapport présenté par le jury d'examen, composé de

Directeur de thèse Monsieurle Docteur Cristian Palmiere

Co-Directeur de thèse

Expert

Vice-Directeur de

l'Ecole doctorale

Monsieur le Professeur John Prior

la Commission MD de l'Ecole doctorale autorise l'impression de la thèse de

\section{Madame Emilienne DESCLOUX}

intitulée

Endocan concentrations in postmortem serum, vitreous humor and urine in victims of lethal hypothermia

Lausanne, le 19 septembre 2017

pour Le Doyen

de la Faculté de Biologie et de Médecine

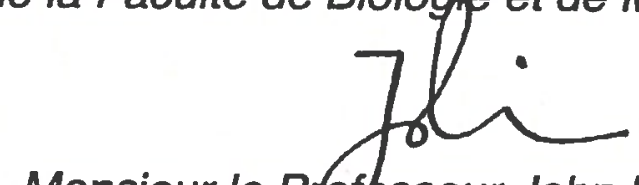

Monsieur le Professeur John Prior

Vice-Directeur de l'Ecole doctorale 


\section{Résumé}

L'endocan est une molécule présente à la surface des cellules endothéliales et sécrétée par les cellules endothéliales de divers organes. Bien que sa fonction exacte chez l'être humain reste à éclaircir, I'hypothèse d'une augmentation de l'expression tissulaire ou de la concentration sérique de cette molécule comme indicateur d'activation endothéliale et/ou de néovascularisation a été formulée.

Dans le domaine forensique, les études menées sur l'activation endothéliale sont limitées essentiellement à l'inflammation systémique et à l'exposition au froid. Concernant cette seconde situation, trois études ont notamment mis en évidence une diminution significative de la thrombomoduline (protéine transmembranaire spécifique aux cellules endothéliales) dans l'urine chez les sujets décédés d'hypothermie par rapport à des cas-contrôle, par ailleurs corrélée à une augmentation des catécholamines urinaires (marqueur biochimique d'exposition au froid). Concernant l'inflammation systémique, une seule étude postmortem a montré une augmentation de l'endocan, par ailleurs corrélée à l'augmentation de la procalcitonine et de la protéine C-réactive, lors de sepsis provoqués par des infections bactériennes, dans le sérum postmortem.

Notre étude a pour but d'évaluer la concentration d'endocan chez des victimes d'hypothermie dans des échantillons respectivement de sérum postmortem de sang périphérique, d'urine et d'humeur vitrée. Les échantillons ont été prélevés durant les autopsies réalisées pour une série de cas ayant bénéficiés d'investigations médico-légales. Au total 76 cas d'autopsies médico-légales ont été sélectionnés, répartis en trois groupes (hypothermie, sepsis et contrôle). Les résultats obtenus indiquent que les valeurs d'endocan dans le sérum postmortem, l'humeur vitrée et l'urine sont augmentées dans le groupe " sepsis ", pour lesquels l'humeur vitrée et l'urine semblent être une alternative au sérum postmortem. Les cas d'hypothermie (exposition au froid uniquement, sans réchauffement) ne semblent quant à eux pas caractérisés par un état inflammatoire menant à une activation endothéliale significative.

En conclusion, compte tenu d'une possible activation de l'endothélium en cas d'exposition au froid évoquée dans la littérature, des investigations ultérieures axées sur d'autres marqueurs d'activation endothéliales devraient être envisagées. 


\title{
Endocan concentrations in postmortem serum, vitreous humor and urine in victims of lethal hypothermia
}

\author{
Emilienne Descloux ${ }^{a}$, Marc Augsburger ${ }^{a}$, Grzegorz Teresiński ${ }^{b}$, Petr Hejna ${ }^{c}$, \\ Eric Grouzmann ${ }^{d}$, Maria Pia Scarpelli a, Tania Hervet a , Cristian Palmiere ${ }^{\text {a. }}{ }^{\circ}$ \\ - University Centre of Legal Medicine, Lausanne University Hospital (CHUV), Lausanne. Swizerland \\ b Chair and Deparment of Forensic Medicine, Medical University of Lublin, Lublin. Poland \\ 'Department of Forensic Medicine, Charles University, Faculty of Medicine and University Hospital Hrodec Krälove, Czech Republic \\ 'Service de Biomédecine, Lausanne University Hospital (CHUV). Lausanne, Swizzerland
}

\section{A R TICLE I NFO}

\section{Article history:}

Received 1 March 2017

Received in revised form

28 June 2017

Accepted 2 July 2017

Available online 4 July 2017

\section{Keywords:}

Hypothermia

Endocan

Endothelium

Autopsy

Postmortem serum

Urine

Vitreous humor

Postmortem biochemistry

\begin{abstract}
A B S T R A C T
Endocan is a soluble molecule secreted from vascular endothelial cells of various organs. Its exact function in humans remains to be elucidated, though it has been postulated that increased tissue expression or serum levels of this molecule may be an indicator of endothelial activation and neovascularization. In the realm of forensic pathology. studies pertaining to endothelial activation following exposure to cold exclusively focused on thrombomodulin, a transmembrane protein specific to endothelia! cells. In the study herein described, endocan concentrations were determined in postmortem serum, urine and vitreous humor samples collected during autopsy in a series of cases that underwent medicolegal investigations. A total of 76 autopsy cases were selected and three study groups (hypothermia group, sepsis group and non-hypothermia/non-sepsis group) prospectively formed during the study period. The obtained results seem to indicate that exposure to cold and subsequent death is not distinguished by significant endothelial dysfunction causing enhanced endocan secretion.
\end{abstract}

- 2017 Elsevier Ltd and Faculty of Forensic and Legal Medicine. All rights reserved.

\section{Introduction}

Endocan, originally termed endothelial cell-specific molecule-1, is an endothelial cell-associated proteoglycan expressed and secreted by activated endothelial cells. These are preferentially of the lung, though less intensively of renal vasculature, in response to pro-inflammatory cytokines, such as tumor necrosis factor (TNF)- $\alpha$, and pro-angiogenic growth factors, such as vascular endothelial growth factor (VEGF). ${ }^{1-5}$

Freely circulating endocan has been found at low levels in the serum of healthy subjects. It has been observed over-expressed in malignant tissues such as melanoma and glioblastoma as well as renal and lung cancer, with the expression level directly correlating to disease severity. ${ }^{1,6-12}$

Further clinical investigations have reported increased endocan

\footnotetext{
- Corresponding author. Unlversity Center of Legal Medicine, Chemin de la Vullierte 4. 1000, Lausanne 25, Switzerland.
}

E-mail address: cristian, palmiere chuv.ch (C. Palmiere). levels in patients with sepsis, severe sepsis and septic shock compared to healthy individuals, thereby suggesting that this molecule could be acknowledged as a suitable biomarker of endothelial dysfunction and multi-organ failure in these situations. ${ }^{13-15}$

In the realm of forensic pathology, endothelial activation/ dysfunction following suspected prolonged exposure to cold has been sporadically studied. One of the rare examples is provided by levels of thrombomodulin, a transmembrane protein specific to endothelial cells. On the other hand, endothelial activation/ dysfunction following bacterial infections causing increased endocan concentrations in postmortem specimens has been investigated only in sepsis-related deaths. ${ }^{16.17}$

In the study herein described, endocan values were determined in three biological samples (postmortem serum from femoral bload, vitreous humor, and urine) in a series of cases that underwent medicolegal investigations that included suspected hypothermia, sepsis and non-hypothermia/non-sepsis cases. Since endocan values in postmortem specimens have been measured exclusively in sepsis-related fatalities, these were chosen as study 
group to compare to hypothermia deaths. Endocan measurements in urine samples were performed based on the results of recent clinical studies.

The first aim of our analyses was to characterize endocan concentrations in the collected samples and thus evaluate their diagnostic potential in identifying endothelial activation in hypothermia fatalities. The second aim was to compare postmortem serum endocan levels to urine and vitreous concentrations in order to explore the usefulness of using urine and/or vitreous as alternatives to postmortem serum for diagnostic purposes.

\section{Materials and methods}

\subsection{Study design and study populations}

The present study was conducted during the period from 2012 to 2016. A total of 76 forensic autopsy cases ( 56 males and 20 females) with a mean age of 46.7 years (range 19-72) were selected and three study groups prospectively formed.

The first group consisted of 31 hypothermia fatalities ( 23 males and 8 females), the second of 14 sepsis-related fatalities ( 9 males and $\mathbf{5}$ females) and the third of 31 non-hypothermia/non-sepsis cases ( 24 males and 7 females).

All cases included in the hypothermia group originated from forensic practice and underwent medicolegal investigations as requested by local inquiring authorities. Postmortem intervals (defined as the time elapsed between body discovery and specimen collection) ranged from $4 \mathrm{~h}$ to $72 \mathrm{~h}$.

The cause of death was considered to be hypothermia on the basis of the following criteria:

- Circumstantial elements suggesting antemortem cold exposure, with no rewarming between cold exposure and death

- Autopsy and histology findings suggesting cold exposure, according to the forensic literature

- Postmortem biochemical investigation results supporting the diagnosis of hypathermia, according to the forensic literature

- Exclusion of other causes of death based on all postmortem investigation findings, including negative toxicology

All cases included in the sepsis group concerned deaths occurring outside the hospital, which underwent medicolegal investigations as requested by local inquiring authorities. These were performed between 5 and $62 \mathrm{~h}$ after death. Inclusion criteria for this group included:

- Circumstantial elements suggesting bacterial infections

- Macroscopic and microscopic findings possibly indicating bacterial infections

- Postmortem biochemical investigation results supporting the existence of generalized inflammation at the time of death

- Exclusion of other causes of death based on all postmortem investigation findings

Non-hypothermia/non-sepsis cases included 16 cases characterized by a short survival time (or short agony, defined as a period of a few seconds up to a few minutes, including cases of sudden cardiac deaths and cases of hanging) and 15 cases characterized by a long survival time (or long agony, defined as a period lasting from a few minutes up to hours, including cases of drug intoxication and stab wounds).

All subjects included in this group originated from forensic practice and underwent medicolegal investigations as requested by local inquiring authorities between 12 and $48 \mathrm{~h}$ after death.

Inclusion criteria for this group included:
- Postmortem interval not exceeding $48 \mathrm{~h}$

- Exclusion of vascular injuries, trauma, cancer, bacterial infection and cold exposure as the main or contributory causes of death

\subsection{Sample collection}

Femoral blood samples were collected from the femoral vein(s) and centrifuged immediately post collection. After centrifugation, the separated supernatant (postmortem serum) was collected and stored in preservative-free tubes. All samples were immediately frozen after collection and kept frozen until analysis.

Undiluted vitreous humor samples were obtained by aspiration using a sterile needle and syringe. Right and left vitreous samples were collected through a scleral puncture at the lateral canthus, aspirated from the centre of each eye, pooled in the same syringe and mixed together. All samples were immediately frozen after collection and kept frozen until analysis.

Urine samples were collected by bladder aspiration using a sterile needle and syringe during postmortem examination. Urine samples were collected in preservative-free tubes without acidification. All specimens were frozen after collection and kept frozen until analysis.

\subsection{Laboratory assays}

Endocan concentration in postmortem serum from femoral blood, urine and vitreous humor was measured by enzyme-linked immunosorbent assay (DIY ELISA Kit EndoMark ${ }^{\infty} \mathrm{H} 1$ Lunginnov, Lille, France). Results were expressed in $\mathrm{ng} / \mathrm{ml}$.

The analytical sensitivity was $0.200 \mathrm{ng} / \mathrm{ml}$, according to manufacturer information. Additional postmortem biochemical investigations were performed according to laboratory standards. internal quality control protocols, and previously described techniques.

\subsection{Statistical analysis}

Data were analyzed using GraphPad Prism software 6.0 (published by GraphPad Software, Inc. La Jolla, CA, USA) as a statistical unit. Endocan concentrations in postmortem serum, urine and vitreous humor in hypothermia-related deaths, sepsis-related deaths and non-hypothermia/non-sepsis cases were compared non-parametrically by the Mann-Whitney $U$ test. $P$ values less than 0.05 were considered statistically significant. The relationship among endocan concentrations in postmortem serum, urine and vitreous was also explored. Endocan cutoff levels discriminating hypothermia-related deaths, sepsis-related deaths and nonhypothermia/non-sepsis cases in all tested samples were not preliminarily identified.

\subsection{Ethics}

All relevant ethical issues were discussed with the local ethics committee. All analyzed biological samples are routinely collected during autopsy for toxicological and/or biochemical purposes in all the medico-legal centers involved in this study. All samples were anonymized prior to analysis and analyzed in the same laboratory. Hence, ethics committee approval to perform biochemical analyses in the selected cases was not necessary.

\section{Results}

Endocan concentrations (ranges) in postmortem serum, urine and vitreous humor in hypothermia-related deaths, sepsis-related 
deaths and non-hypothermia/non-sepsis cases are summarized in Table 1.

Additional biochemical and toxicological analyses failed to provide further information to the interpretation of endocan values, so results were not reported in Table 1.

No correlation between endocan concentrations and postmortem period was observed in any of the studied group. Additionally, no correlation was observed between endocan values and survival time in the non-hypothermia/non-sepsis cases in any of the analyzed specimens.

In the hypothermia group, endocan levels were undetectable in postmortem serum in 26 out of 31 cases, in urine in 28 out of 31 cases and in vitreous humor in $\mathbf{2 5}$ out of $\mathbf{3 1}$ cases.

In the sepsis group, the presence of the molecule was systematically recorded in the three tested samples. Values ranged from $0.612 \mathrm{ng} / \mathrm{ml}$ to $3.934 \mathrm{ng} / \mathrm{ml}$ in postmortem serum, from $0.989 \mathrm{ng} / \mathrm{ml}$ to $4.069 \mathrm{ng} / \mathrm{ml}$ in urine, and from $0.419 \mathrm{ng} / \mathrm{ml}$ to $3.665 \mathrm{ng} / \mathrm{ml}$ in vitreous humor.

In the non-hypothermia/non-sepsis group, endocan levels were undetectable in postmortem serum in 27 out of 31 cases, in urine in 28 out of 31 cases and in vitreous humor in 26 out of 31 cases.

No difference was observed in the non-hypothermia/non-sepsis group in endocan levels (in any of the sampled fluid) in any of the studied subgroups.

Postmortem serum endocan levels were significantly higher in the sepsis group than in hypothermia (5 detectable values) and non-hypothermia/non-sepsis cases (4 detectable values). Analogously, urine and vitreous endocan concentrations were significantly higher in the sepsis group compared to hypothermia ( 3 and 6 detectable values, respectively) and non-hypothermia/non-sepsis cases ( 3 and 5 detectable values, respectively).

Analysis of the results obtained from endocan measurements in postmortem serum, urine and vitreous humor did not reveal statistically significant differences between hypothermia-related deaths and non-hypothermia/non-sepsis individuals.

Lastly, a positive moderate correlation was observed in the sepsis group between endocan concentrations in postmortem serum and urine $(r=0.64)$ as well as between endocan concentrations in postmortem serum and vitreous humor $(r=0.69)$.

Overall, these results suggest that postmortem serum, urine and vitreous levels of endocan are increased in sepsis-related deaths, in which urine and vitreous appear to be suitable alternatives to postmortem serum for diagnostic purposes. Conversely, postmortem serum, urine and vitreous endocan levels are of no value in cases of suspected hypothermia-related death and cannot be reliably used in the forensic setting to support the diagnosis of hypothermia.

\section{Discussion}

Despite promising advances in several fields of forensic research in recent years, the postmortem identification of hypothermia fatalities remains challenging. The diagnosis is mainly based on the exclusion of alternative causes of death and the assessment of circumstantial evidence. There are currently no optimal tools with which to estimate the severity and significance of antemortem cold exposure. In addition, autopsy and histology findings results may vary considerably from case to case and be influenced by numerous factors and circumstances, thus rendering them only possible indications of antemortem cold exposure. Exposure to cold is characterized by significant stress reactions that enhance catecholamine and counter-regulatory hormone release. Urinary catecholamine and metanephrine levels have been reported to increase in hypothermia fatalities. Though their measurement is recommended in forensic pathology routine for the diagnosis of cold-related stress and deaths, normal levels in suspected hypothermia fatalities do not allow this diagnosis to be excluded. ${ }^{17-19}$

In humans and other homoeothermic animals, the ability to maintain a constant body temperature depends on thermoregulatory mechanisms and sensory inputs from temperature receptors located in central and peripheral sites, including in the skin. ${ }^{20-25}$

Simpathoadrenal system activation during cold exposure leads to increased plasma levels of catecholamines, most importantly adrenaline and noradrenaline, which have immediate, significant effects on blood circulation, vessel walls (by enhancing and supporting peripheral vasoconstriction), skeletal muscle (by enhancing heat production) and other cells. ${ }^{7-19}$

Though simpathoadrenal system activation in the first phases of cold exposure is a requirement for survival responses in lifethreatening conditions, prolonged activation has deleterious effects on several organs, including vessels. High blood catecholamine levels may damage vascular endothelium causing local edema, endothelial cell swelling, necrosis and progressive destruction, thereby aggravating the direct effects of cooling on the vascular wall. ${ }^{21-25}$

In the realm of forensic pathology, endothelial activation or dysfunction following cold exposure has been occasionally investigated from both the morphological and biochemical points of view.

In a study focusing on vital reactions to frostbite in guinea pigs exposed to a temperature of $-20^{\circ} \mathrm{C}$ (average exposure 4-5 h) until a rectal temperature of $30^{\circ} \mathrm{C}$ was reached (and subsequent rewarming to $39{ }^{\circ} \mathrm{C}$ in a subgroup of animals), Hirvonen ${ }^{27.28}$ observed that few morphological changes were detectable in fresh premortem frostbite cases despite hours of cold exposure, with only slight inflammatory reactions involving granulocytes observed in the initial phase. In addition, this inaugural inflammation could not be observed in any of those cases in which no thawing had been allowed to take place. Hirvonen concluded that one reason for these slow, histologically identifiable vital reactions to frostbite was probably the vasoconstriction that occurs under cold conditions, keeping precapillary arteries constricted unless the

Table 1 Summarizes the main resuls obtained in the studied groups. Endocan concentrations (range) and medians in postmortem serum, urine and vitreous humor in septic cases
were expressed in $\mathrm{ng} / \mathrm{mL}$.

\begin{tabular}{lll}
\hline $\begin{array}{l}\text { Studied group } \\
(\mathrm{n}=76)\end{array}$ & $\begin{array}{l}\text { Postmortem serum } \\
\text { (range) }\end{array}$ & $\begin{array}{l}\text { Urine } \\
\text { (range) }\end{array}$ \\
\hline $\begin{array}{l}\text { Hypothermia } \\
(\mathrm{n}=32)\end{array}$ & $<0.200-0.325$ & $<0.200-0.927$ \\
$\begin{array}{l}\text { Sepsis } \\
(\mathrm{n}=14)\end{array}$ & $0.612-3.934$ & $\begin{array}{l}\text { Vitreous humor } \\
\text { (range) }\end{array}$ \\
$\begin{array}{l}\text { Median } \\
\text { Non-hypothermia/non-sepsis cases }\end{array}$ & & $0.989-4.069$ \\
$(\mathrm{n}=31)$ & 1.917 & 2.173 \\
\end{tabular}


skin thaws. If rewarming occurs, hyperemia follows thawing only in those parts of tissues where the vesseis are not completely necrotized, and leucocytes are able to gather solely in the functioning venules and then invade surrounding tissues.

The behavior of thrombomodulin, a transmembrane protein specific to endothelial cells, whose soluble forms have been used to estimate endothelial injuries, was investigated by Pakanen and coworkers ${ }^{17,26,29}$ in plasma, urine, serum, heart tissue and myocardial blood vessels in a series of situations including animals (rats) exposed to cold, hypothermia fatalities in humans who had undergone medicolegal investigations, and healthy human volunteers immersed in cold and warm water. Among other findings, these authors observed that thrombomodulin levels in urine were significantly lower in hypothermia fatalities than in individuals with other causes of death and compared with baseline values of healthy living subjects. In addition, according to the results of these studies, urinary thrombomodulin levels in hypothermia deaths correlated significantly with increased urine catecholamine concentrations.

Endocan is a $50-\mathrm{kDa}$ proteoglycan that is composed of dermatan sulfate and a mature polypeptide of 165 amino acids. Unlike other ubiquitous proteoglycans, which are mainly located in connective tissue, endocan is a soluble molecule, secreted from vascular endothelial cells of various organs, able to freely circulate in blood. The exact role of endocan in humans remains to be elucidated, though it has been postulated that increased tissue expression or serum levels of this molecule may be an indicator of endothelial activation (inflammation) and neovascularization (tumor progression). ${ }^{30.31}$

Urinary concentrations of endocan have been recently investigated in individuals suffering from bladder cancer, urinary tract infections and healthy volunteers. It has been observed that serum and urine endocan concentrations were significantly higher in patients with bladder cancer than in healthy volunteers, though endocan concentrations in serum and urine were not significantly different in patients with bladder cancer and those with urinary tract infections. ${ }^{325}$

The results of the study presented herein seem to indicate that hypothermia fatalities following exposure to cold (with no supposed rewarming between cold exposure and subsequent death) are not characterized by appreciable generalized inflammation and endothelial activation leading to increased endocan concentrations in postmortem serum, urine or vitreous humor collected at autopsy. These results appear to be in agreement with the conclusions of former reports, which failed to measure increased postmortem serum procalcitonin and C-reactive protein in hypothermia deaths compared to non-hypothermia ones. ${ }^{33}$

Furthermore, our results would indirectly support the conclusions of the studies by Hirvonen, ${ }^{27,28}$ who did not objectify histologically significant inflammatory reactions to frostbite in animals exposed to a temperature of $-20^{\circ} \mathrm{C}$, despite an average exposure of 4-5 h, unless rewarming had occurred. As stated above, Hirvonen speculated that the peripheral vasoconstriction characterizing cold exposure was most likely responsible for the slowness of histologically identifiable vital reactions to frostbite in the absence of rewarming after cold exposure.

It must be highlighted that the results of our study are less susceptible to be compared to those reported by Pakanen and coworkers, 17,26,29 who manifestly found significantly decreased thrombomodulin levels in urine in hypothermia fatalities compared to non-hypothermia cases, as well as decreased soluble thrombomodulin in serum. Albeit, the difference between hypothermia fatalities and non-hypothermia cases was not statistically significant in the latter specimen. On the other hand, these authors observed that severe hypothermia in rats caused an initial decrease in blood thrombomodulin concentrations followed by an increase after prolonged cold exposure, and opposite changes in urine.

Lastly, our findings appear to confirm previous observations pertaining to detectable, measurable endocan concentrations in postmortem serum in sepsis-related fatalities. Furthermore, significant associations were observed in our study between postmortem serum endocan levels and urine/vitreous values. This result is undoubtedly interesting since no associations had been identified between postmortem serum endocan values and pericardial fluid levels in either septic or control cases. ${ }^{16}$

This is the first study, to our knowledge, to investigate the biochemical profile of endocan in postmortem serum, urine and vitreous humor in a series of medicolegal cases including hypothermia fatalities, sepsis-related deaths and non-hypothermia/ non-sepsis cases that underwent medicolegal investigations. We were unable to find similar studies in the forensic setting with which to compare our results.

The limitations of our study must be acknowledged. The most important is the relatively small number of studied cases, which may limit the accuracy of our research. However, precise selection criteria were applied during the recruitment process in all study groups to minimize heterogeneity in the study populations. Prospective investigations including a greater number of subjects would therefore be needed to confirm our findings.

Thus, even though further studies are required to confirm these preliminary observations, our results seem to indicate that exposure to cold and subsequent death is not distinguished by detectable inflammatory responses and endothelial dysfunction causing enhanced endocan secretion from vascular endothelial cells. Considering that findings pertaining to thrombomodulin behavior in hypothermia fatalities seem to suggest an endothelial reaction to cold exposure of a different type, additional biochemical investigations are needed. These should potentially involve several different biomarkers of endothelial activation and could pose a topic of interest and future research in order to better understand pathophysiological changes of the vascular wall following severe cold exposure and subsequent death in humans.

\section{Role of funding source}

This paper was not financially supported.

\section{Conflicts of interests}

None.

\section{References}

1. Kali $\Lambda$, Shetty KS. Endocan: a novel circulating proteoglycan. Indian J Pharınacol. 2014:46:579-583.

2. Kechagia M. Papassotiriou I, Gourgoulianis KI. Endocan and the respiratory system: a review. Int J Chron Obstruer Pulmon Dis. 2016:11:3179-3187.

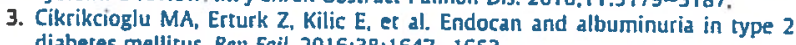
diabetes mellitus. Ren Fail. 2016;38:1647-1653.

4. Lassalle P. Molet S, Janin A, et al. ESM-1 is a novel human endotheilal cellspecific molecule expressed in lung and regulated by cytokines. J Biol Chem. 1996:271:20458-20464.

5. Lee YH, Kım JS, Kim SY, et al. Plasma endocan level and prognosis of Immunoglobulin A nephropathy. Kidney Res Clin Pract. 2016:35:152-159.

6. Abid MR, Yi X. Yano K, Shih SC. Aird WC. Vascular endocan is preferentially expressed in tumor endothelium. Microvase Res. 2006:72.136 - 145.

7. Chen LY. Liu $X$, Wang SL. Qin CY. Over-expression of the endocan gene in endothelial cells from hepatocellular carcinoma is associated with angiogenesis and tumour invasion. J lint Med Res. 2010;38:498-510.

8. Delehedde M. Devenyns L. Maurage CA. Vivés RR. Endocan in cancers. a lesson from a circulating dermatan sulfate proteoglycan. Ini J Cell Biol. 2013;2013: 705027.

9. Grigoriu BD, Depontieu F, Scherpereel A. et al. Endocan expression and relationship with survival in human non-small cell lung cancer. Clin Cancer Res
2006:12:4575-4582. 
10. Leroy X. Aubert S, LIni L, et al. Vascular endocan (ESM-1) is markedly overexpressed in clear cell renal cell carcinoma Histopathology. 2010:56:180-187.

11. Maurage CA. Adam E. Mineo JF, et al Endocan expression and localization in human glioblastomas. J Neuropath Exp Neural. 2009,68:633-641.

12. Sarrazin $S$. Adam $t$, Lyon $M$, et al. tendocan or endothelial cell specific molecule 1 (ESM-1). a porential novel endotheltal cell marker and a new target for cancer lliciapy. Biochim Biophys Acta 2006,1765:25-37.

13. Hep JC endocan or endothelial cell-specific molecule-1: a novel prognostic marker of sepsis? Cris Care Med 2006.34.574-575.

14. Pauly D. Hamed S. Behnes $M$. et al. Endothelial cell-specific molecule-1/ endocan diagnosic and prognostic value in patients suffering from severe sepsis and septic shock. J Crit Care. 2016,31:68-75

15. Scherpereel A. Depontieu F, Grigoriu B, et al. Endocan, a new endothelia marker in human sepsis. Crit Care Med, 2006:34(2):532-537.

16. Palmiere C. Augsturger M. Endocan measurement for the postmortem diagnosis of sepsis. Leg Med (Tokyo). 2014:16:1-7,

17. Pakanen L, Kaija H. Kortelainen ML. Sarkioja T. Porvari K. Vicrims of lethal hypothermia have decreased levels of thrombomodulin in myocardium and urine. Int J Leg Med. 2015:129:289-296.

18. Pakanen L. Kortelainen ML Sarkioja T, Porvari K Increased adrenaline to noradrenaline ratio is a superior indicator of antemortem hypothermia $1213-1218$.

19. Palmiere C. Teresinski G, Hejna P. Mangin P. Grouzmann E. Diagnostic performance of urinary metanephrines for the postmortem diagnosis of hypo thermia. Forensic Sci Med Parhol. 2014:10:518-525.

20. Benzinger TH. Heat regulation: homeostasis of central temperature in man Physiol Rev. 1969:49:671-759.

21. Fealey RD. Interoception and autonomic nervous system reflexes thermoregulation. Handb Clin Neurol. 2013:117:79-88.
22. Romanovsky AA. Thermoregulation: some concepts have changed. Functional architecture of the thermoregulatory system Am J Physiol Regul Integr Coinp Mhysiol. 2007;292:R37-R4G.

23. Brown D]. Brugger $H$. Boyd J. Paal 1'. Accidental hypotherma $N$ Engl J Med 2012:367:1930-1938.

24. Long 3rd WB. Edlich Rr. Winters KL. Britt LD Cold injuries J tong Jern EJJ Med Iimplants. 2005:15:67-78.

25. Ulrich AS, Rathlev NK. Hypothermia and localized cold injuries. tinerg Mled Clin North Am. 2004:22:281-298.

26. Kaija H, Pakanen L Uusitalo J. Nikkila S. Korrclatnen ML. I'orvari KS. Changes in cardiac thrombomodulin and heat shock transcription factor 1 expiession and peripheral thrombomodulin and catecholatnines during hypothermia in rats. Stress. 2014:17:504-511

27. Hirvonen J Vital reactions to frostbite of the ear and paw skin in Guinea pigs exposed to the cold. $Z$ Rechtsined $1990,103: 249-256$,

28. Hivonen J. Penttinen J, Huttunen P. Histologically demonstrable vital reaccion to frostbite in Guined pigs dying of hypothermia. Z Rechitsmed. $1982,89 \cdot 81-88$

29. Pakanen L. I'aakkonen T. Ikaheino TM, et al. Urinary thrombomodulin and catecholamine tevels are interrelated in healthy volunteers immersed in cold and warm water. Temp (Austim). 2015;3:161-166.

30. Seo K, Kitazawa T, Yoshino Y, Koga I, Ota Y. Characteristics of serum endocan levels in infection. Plos One. 2015;10:e0123358.

31. Zuo L, Zhang SM, Hu RL, er al. Correlation between expression and differentiation of endocan in colorectal cancer. World J Gastrocnterol. 2008:14: $4562-4568$.

32. Laloglu $E$, Aksoy H. Aksoy Y. Ozkaya F. Akcay F. The determination of serum and urinary endocan concentrations in patients with bladder cancer. Ann Clin Biochem. 2016;53:647-653.

33. Palmiere $C$, Bardy $D$, Letovanec $I$, et al. Blochemical markers of fatal hypo thermia. Forensic Sci Int. 2013:226:54-61. 